\title{
Study on the Cultivation Mode of Accounting Talents in School-enterprise Cooperation
}

\author{
Chen Yuting ${ }^{1}$ \\ ${ }^{1}$ Huashang Vocational College, Guangzhou, Guangdong, 511300
}

Keywords: vocational education; school-enterprise cooperation; personnel training mode

\begin{abstract}
Through the analysis of the present situation of the development of higher vocational education and accounting personnel training, this paper reveals the problems existing in the training of accounting professionals in higher vocational education. Through the understanding of the connotation of the training model of accounting professionals in higher vocational colleges and the proof of the protection of accounting personnel training mode in school-enterprise cooperation, and through the research and analysis, it is concluded that the training mode of accounting personnel based on the cooperation between school and enterprises is the core of higher vocational education. It is also a kind of talent training mode conclusion of achieving win-win situation among enterprises, schools and students, which is helpful for higher vocational colleges to cultivate highly qualified applied talents with accounting skills.
\end{abstract}

\section{The Development and Status Analysis of Accounting Personnel Training in Higher Vocational Education}

In higher vocational education, we attach more importance to the professional and technical education of students, emphasize students' hands-on practical ability, attach importance to cultivating skilled talents and advocate the employment-oriented guiding principle. Higher vocational education according to a certain job positions (group) the scope of the actual business activities, training first-line practical (technical or occupational) talent. This kind of education places more emphasis on professional pertinence and vocational skill ability training, and is based on the demand of social talent market-oriented employment education. As an important part of the coordinated development of education and an important way to promote employment, vocational education clearly states that it is necessary to "perfect the system of vocational education and training, deepen the integration of industry and education and the cooperation between schools and enterprises", pointing out the direction for the development of vocational education [1].

On the afternoon of November 4, 2017, the 30th meeting of the 12th NPC Standing Committee voted to pass the decision on the revision of the accounting law and formally changed the stipulation of "personnel engaged in accounting work must obtain the accounting qualification certificate" As "accountants should have the necessary professional ability to engage in accounting work." "Accounting Law" amendment content November 5, 2017 After the formal implementation, more talents will be attracted to the accounting profession to promote financial workers Improve their own ability to improve the overall quality of the industry. But with the addition of talented people, competition in the accounting profession will become even more intense. Therefore, the cultivation of accounting talents in higher vocational education not only emphasizes students 'mastery of theoretical knowledge, but also emphasizes the cultivation of practical ability of students. Combining practical work with accounting theory is a necessary method to improve students' practical ability in accounting [2].

At present, the main problems existing in vocational accounting professionals training are:

(1) Accounting professional training mode is not clear

At present, many higher vocational colleges are still at a stage of exploring talent cultivation mode, and their thinking is not clear. Curriculum and teaching content system are also in a perfect stage. Curriculum to reflect the practical operation of the curriculum set up small, training students to practice innovative ability to do little. Laboratory construction and training base construction lag, 
production and research combined not close enough. All of these have a direct impact on the cultivation of high quality applied accounting talents in higher vocational colleges.

(2) Lack of practical experience of teachers

In order to cultivate high-quality skilled personnel with applied talents, higher vocational colleges must pay attention to the construction of teachers' team, especially to the construction of professional teachers. Accounting professional teachers in higher vocational colleges not only need to have a solid, systematic theoretical knowledge, but also must have some practical experience and proficiency in operational skills. However, at present, there is a long way to go in terms of accounting professional teachers in higher vocational colleges. Some young accounting teachers do not have practical experience in accounting. This shows that the construction of teaching staff is still a key issue that should not be ignored in vocational accounting cultivation.

(3) There is a big gap between students' basic ability and accounting professional ability requirements

There is a certain difference between the theoretical education of schools and the demand ability of the actual post. The accountants of the enterprises often need to communicate with departments such as tax bureaus, banks and other units, and need some coordination of professional knowledge and interpersonal communication [2]. In the face of rapid development accounting-related policies, enterprises also attach importance to accountants of independent learning ability and independent thinking ability. In general, when choosing accounting talents, enterprises pay more attention to students' ability of communication and coordination, positive attitudes and behaviors, and their ability to continuously study, think and solve problems autonomously. Students through the school's theoretical education, to master some basic theoretical knowledge, but students lack hard-working perseverance and spirit, overemphasize personality development, teamwork spirit is not strong, organizational discipline is weak, the sense of responsibility is not strong, in practical work, Students are more likely to be relieved of internship agreements with enterprises and so on. These also hold back the cultivation of higher vocational accounting personnel development, is not conducive to vocational training in line with the actual needs of enterprises in the technical skills professionals.

\section{The Connotation of Accounting Professional Training Model}

Accounting professionals training mode is to run in the training process in order to achieve the goal of training high-quality technical and accounting talents, mainly by the accounting profession setting, curriculum setting, teaching design and method, teaching staff construction, practice teaching Elements such as composition [2].

The training of accounting professionals mainly from two aspects, on the one hand the accounting profession students in accounting professional positions necessary professional theory basic knowledge, basic skills and professional quality of training, on the other hand to strengthen school-enterprise cooperation and common with enterprises Explore and form a training program of innovative talents with students as the main body, ability training as the center, face to the front line, base on posts, basic enough, focus on quality, strengthen application, highlighting the ability of knowledge, ability and quality to achieve professional and business Position docking, so that "two to strengthen", that is, to strengthen the practice of teaching, to strengthen the training of innovative ability. The ultimate goal of accounting professionals to achieve the basic practical ability training, professional and technical ability to apply, problem solving ability, ability to train innovative goals.

\section{School-enterprise Cooperation is the Basic Guarantee for Accounting Personnel Training Mode}

According to the actual situation of higher vocational education and students, the vocational education under the cooperation of school and enterprise will integrate the actual and the theory, train the students to adapt to the overall quality of society, pay more attention to the cultivation of students' practical ability and professional accomplishment. 
In 2017, our school introduced the "teaching integration" school-enterprise cooperation training project and adopted the professional education model of "doing middle school and learning by doing", showing distinctive characteristics of accounting professional training and achieving obvious results. "Integrated teaching method" that is the theory of practice integrated teaching method. It breaks the framework of "discipline" and "systematic" teaching mode of traditional higher vocational education. It no longer separates theory from practice, but emphasizes the principle of "practicality and moderation" of the theoretical knowledge of teaching and emphasizes the teaching In the core of the student's skills training, theory and practice at the same time, students in "learning", teachers in "doing teaching" to complete the theoretical teaching and internship guidance [3].

Through the "teaching integration" teaching by the cooperation between school and enterprise, students can master the skills and relevant basic theoretical knowledge that accounting posts should possess in practical work so that students can get started quickly and have competent work Confidence, the practice of the implementation of the class a direct impact on the employment competitiveness of students, therefore, to improve the combination of accounting simulation training and theoretical teaching, and enhance students' ability. In teaching, you can imitate the accounting of enterprises, assign corresponding accounting roles and assign tasks to students so that students can actively collect information and discuss with each other so as to solve problems and improve students' basic skills of cost accounting [4].

The actual case proves that the implementation of the teaching-integrated teaching mode of school-enterprise cooperation is the key to the development of vocational schools. The cooperation between school and enterprises is the basic guarantee of the training mode of accounting professionals. The cooperation between school and enterprise fully embodies the characteristics of vocational education, pay attention to the relationship between skills training and theory, pay attention to professional characteristics and industry requirements, pay more attention to students' innovative spirit, cooperation awareness and comprehensive vocational ability training. Through the "integrated" teaching practice of school-enterprise cooperation, for enterprises, enterprises can participate in the training to cultivate professional talents that better meet the needs of enterprises. As far as schools are concerned, the school has made a qualitative leap in understanding of accounting professionals, paying more attention to students' practical ability to practice and practicing practical training. For the students, it stimulated students' interest in learning to a great extent, promoted the interaction and dialogue in the teaching process, enabled the students in accounting major to experience the happiness of trying out success, gradually changed their learning styles and cultivated their self-exploration ability And innovative spirit [4].

\section{The Practice of Accounting Personnel Training Mode in School-enterprise Cooperation}

In order to better carry out the accounting personnel training mode reform, we through a large number of enterprises and talent market research, combined with a number of vocational colleges and enterprises formed education and cooperation project, the final analysis of the high school-enterprise cooperation Professional accounting training model can cultivate professionals with basic theoretical knowledge, with innovative ideas and strong ability to work, meet the needs of enterprises with high-quality accounting skills applied talents. The concrete practice of accounting personnel training mode for higher vocational school-enterprise cooperation is described as follows:

\subsection{Highlight the characteristics of accounting professional training model}

\subsubsection{To be well aware of the guiding ideology of accounting professional training}

Higher vocational colleges take the social demand as the guide, take the road of development combining production with study, reform the professional curriculum system and curriculum content, and actively promote the training mode of higher vocational accounting major with the combination of work and study; , Building excellent part-time "double division" structure of 
teachers; to school-enterprise cooperation as a way to deepen cooperation with the accounting industry, business, industry and business resources, and industry and enterprises to jointly carry out professional construction; in order to improve the quality of professional teaching For the purpose of training high-quality skilled accounting professionals.

\subsubsection{To reform the position-oriented curriculum system}

Vocational colleges and universities to implement the cooperation between enterprises, and some tax offices, accounting firms and other enterprises, school-enterprise cooperation regularly educate the Steering Committee, revised personnel training programs and curriculum standards, to maintain the content of professional teaching and practical work is highly consistent.

\subsubsection{To adapt to the "combination of work and study, school-enterprise cooperation"}

According to the characteristics and rules of higher vocational accountants training, we should reform the system of accounting major according to the training mode of "work-study combination, school-enterprise cooperation" and reference to accounting job requirements. In-depth analysis of accounting positions, from the analysis of students' future jobs and job capabilities to determine the typical tasks, analysis of accounting areas of action, and summarize the learning area, the construction of a new curriculum system [5].

\subsubsection{To strengthen teaching materials}

In order to achieve the goal of training accounting professionals, to meet the needs of teaching, senior teachers and organizations to organize the preparation of "Financial Accounting Tutorial", "Accounting Training" handouts and other important course materials and practical exercises supporting exercises [5].

\subsection{To strengthen the "double-oriented" teacher-based teacher team building}

Schools should introduce a series of policies on the introduction of talents by constantly improving teachers' working conditions, housing and allowances, and attracting highly educated teachers and optimizing their academic qualifications. Through the school-enterprise cooperation project, with enterprise practice, academic exchange and academic degree training and other means to cultivate outstanding middle-aged backbone professional teachers. Requirements professional teachers every year for not less than two months of business experience in order to improve their practical skills and to guide students in professional practical training ability; every year to send selected teachers to the domestic vocational education level, the characteristics of institutions to carry out Visit, academic exchanges and degree education, in order to train a group of professional backbone teachers. Strengthen the cooperation between schools and enterprises, employ a group of accounting profession experts as part-time teachers to guide students in practice, so that students can learn real and effective practical skills and experience [6]. Enhance the scientific research level and scientific service ability of teachers by strengthening research and scientific research.

The focus of teacher research is the reform of specialty and curriculum, teaching materials innovation, teaching mode innovation and other teaching reform projects and applied technology research. At the same time, the school set up scientific research incentive system, to maximize the enthusiasm of teachers to mobilize scientific research, and promote the quality of scientific research teachers and improve the level of science and technology services. Accountants full-time teachers to participate in professional groups related to other professional teaching activities, the accounting profession of education and teaching concepts and methods to other professional teaching activities to promote the relevant professional teachers within the professional quality and overall improvement of teaching level. The training of "double-qualified" teachers not only enhances the practical ability of teachers 'teaching, but also enables teachers to apply these new knowledge and skills to professional teaching so as to cultivate students' ability of accounting operation and professional post. Training more professional accounting talents that meet the needs of enterprises [6]. 


\subsection{To strengthen the cooperation between school and enterprise}

Higher vocational colleges should strengthen their close contact with enterprises. Through the establishment of off-campus internship bases, they should actively cooperate with enterprises and employ specialists as members of the school's professional steering committees to make suggestions for the development of schools and accounting professions. They employ business experts to regularly give lectures ; Delivery of student internships and teachers to the enterprise training, the construction of a number of stable, able to carry out the combination of engineering and internship practice base outside the school, so that students go to work in economic entities, to provide the real situation of skills training opportunities to achieve education And positions "zero distance", comprehensively cultivate students 'accounting professional qualities, and provide a good platform for students' practical learning and teacher-to-business training. Vocational colleges have a sound security system to protect the training base outside the school building, can further promote the depth of cooperation between school-enterprise [7].

\section{Conclusion}

Higher vocational colleges aim at the "win-win" of school-based enterprises and the "students' growth and success" as the foundation, forming a training model of accounting personnel for the cooperation between school and enterprise, and better able to train highly qualified accountants who meet the needs of social talents Technical skills applied talents.

\section{Acknowledgement}

This paper is the result of a study on the subject of Guangzhou Huashang Vocational College in 2018 (topic number: Kjy 2016013).

\section{References}

[1] Qi Dianwei. The research and practice of the training mode of high quality and complex talents in accounting specialty [J]. Modern Education Science, 2016,06: 114-119.

[2] Lee Min-ho in the teaching of accounting students to cultivate innovative ability [J]. Vocational Education Forum, 2012,9.

[3] Xu Yanqing. Based on the cooperation between school and enterprise personnel training mode reform [J]. Modern Enterprise Education, 2013, (9): 109.

[4] He Xingguo. Pan Liyun. Vocational Education School-enterprise cooperation practice problems and countermeasures [J]. Education and Careers, 2014 (3).

[5] Lin Bin. Concept and Practical Responsibility of the Cooperation between School and Enterprise in Vocational Education Reform [J]. Journal of Fujian Business College, 2014 (4): $72-78$

[6] Yao Fen. Exploration of moral education in higher vocational school-enterprise cooperation. Journal of Yellow River Conservancy Technical Institute .2008 (10)

[7] Niu Yuxing. Analysis of the Current School-enterprise Cooperation in Higher Vocational Education [J]. Theory of Theory, 2010 (9) 